\title{
The Planning and Compulsory Purchase Act 2004 - how will planning contributions work? I
}

by Michael Cunliffe

This paper was presented at the seminar "Planning and Compulsory Purchase Bill - the practicalities of the law", which was held by the Society for Advanced Legal Studies Planning and Environmental Law Reform Working Group on 21 April. The first part deals with recent proposals for reform and improvement of the planning obligations system - including the clauses added to the Planning and Compulsory Purchase Bill - while the second part contains commentary by the author on the new legislation.

\section{INTRODUCTION}

$\mathrm{S}$ ection 106 of the Town and Country Planning Act 1990 (as substituted by the Planning and Compensation Act 1991) provides that anyone with an interest in land may enter into a planning obligation, created either by agreement or by unilateral undertaking.

The general purpose of planning obligations is to address the impacts of a proposed development and to require the landowner to undertake measures to make the planning application acceptable to the local planning authority. Planning obligations run with the land so that they may be enforced against the original covenantor and against any successor in title. Obligations can be positive or negative; they may be unconditional or subject to conditions; they may impose any restriction or requirement for an indefinite or specified period and may provide for payments of money to be made either for a specific amount or by reference to a formula contained within the obligation and may require periodical payments to be paid indefinitely or for a specified period.

This sounds straightforward. The reality is however that the area of planning obligations has become the most contentious and controversial area of planning law and practice with the perception that planning permissions are being bought and sold. This perception has led to much political and public debate. There have also been criticisms of the system as being inconsistent, uncertain, unfair, lacking in transparency, slow and expensive.

The Government eventually acted on these concerns, having dithered for nearly four years, and on 19 December 2001 it published a consultation paper entitled Planning Obligations: Delivering a Fundamental Change. The consultation paper put forward proposals for reform and improvement of the planning obligations system to make it more open, transparent and predictable. One of the main proposals was the introduction of a tariff system. That provoked considerable public debate, much of a critical nature, and the proposed tariff system was criticised by the House of Commons Select Committee on Transport Local Government and the Regions and condemned by a number of bodies including the CBI and the British Property Federation.

The tariff proposals were suddenly dropped in July 2002 and commentators believed that tariffs had been buried. Not so. Surprisingly, on 6 November 2003 they reemerged in a different guise known as the optional planning charge. In December 2003, clauses were added to the Planning and Compulsory Purchase Bill as it went up through Parliament.

The Act introduces the new concept of planning contributions. In this paper it is proposed:

(i) to consider the background to reform;

(ii) to consider the Government's original proposals for introducing a tariff system as set out in the December 2001 consultation paper;

(iii) to consider the comments made by the House of Commons Select Committee and others on that proposed tariff system;

(iv) to consider the Government's response to the consultation exercise and to the Select Committee's comments;

(v) to consider the Government's proposals for Planning Contributions set out in the further consultation paper issued on 6 November 2003;

(vi) to consider the proposed clauses in relation to planning contributions introduced into the Bill; 
(vii) to consider comments made on the planning contributions provisions in the Bill during its passage through the House of Commons and the House of Lords;

(viii) to consider the ODPM Statement on 30 January 2004;

(ix) to consider the responses to the consultation paper;

(x) to look at the setting up of the Government Task Force;

(xi) to look at the proposal for pilot schemes;

(xii) to look at the Barker Report then to reflect on the planning contribution proposals and

(xiii) to consider how planning contributions will work.

\section{BACKGROUND TO REFORM}

The planning gain system had been the subject of criticism by the development industry for a number of years as being inconsistent, uncertain, unfair, lacking in transparency, slow and expensive. There is a major concern about the opaqueness of the system that feeds the argument that planning permissions are being bought and sold behind closed doors.

Lord Nolan's Committee on Standards in Public Life in its Third Report entitled Standards of Conduct in Local Government (July 1997) found that planning obligations were "the most intractable aspect of the planning system with which we have had to deal (and that they) have a tremendous impact on public confidence". The committee recommended that the Government should consider whether present legislation was sufficiently tightly worded to prevent planning permissions being bought and sold, and that local authorities should adopt rules on openness that would allow planning agreements to be subject to discussion by members of the authority and the public.

In January 1998 the then Planning Minister, Richard Caborn, in response to the Nolan Report, introduced a policy statement, Modernising Planning, which encouraged debate on the use of planning obligations to make them more predictable and transparent. In April 1999, Richard Caborn announced that a consultation paper on planning obligations was planned for that year. Over the following two years there were vague promises that a consultation paper was to be published, but nothing materialised.

Momentum for reform came in June 2001 when the Chancellor of the Exchequer, Gordon Brown, expressed concern about how delays in the planning system generally were inhibiting economic growth and investment and announced that a Green Paper on reforming the planning system would be published later that year. In December 2001 the Green Paper was published and alongside it was a companion consultation paper on planning obligations where the Government put forward its reform proposals and invited comments. The Government's stated aim was to have a system that was open, transparent and predictable.

\section{CONSULTATION PAPER PLANNING OBLIGATIONS - DELIVERING A FUNDAMENTAL CHANGE (DECEMBER 2001)}

The Government's chosen vehicle to reform the planning obligations system to make it more open, transparent and predictable was for a standardised tariff system to be introduced. The Government wanted local planning authorities to operate a tariff system to ensure that development provided social, economic and environmental benefits to the community as a whole in pursuit of sustainable development. The proposal was bearing on a local development tax to be applied by local authorities for social engineering purposes with the tariff payable not being limited to mitigating the impact of a particular development. Any intrinsic link or nexus between a development and meeting the impact or cost of that development would be lost. This was an important philosophical change.

The consultation paper stated that the Government was proposing primary legislation to give the Secretary of State powers to oversee the introduction of a tariff as a requirement to be paid in all qualifying circumstances and new national guidance would be issued about the workings of the new system. It also said that the Government was keen to see tariffs being dealt with through the development plan process which would improve the transparency and predictability of planning obligations.

Local authorities would have discretion to determine the types, sizes and location of development on which the tariff would be charged and how it would apply in different circumstances, subject to national policy guidance. Local authorities would also have a local discretion as to how receipts from tariffs would be spent, again subject to national policy guidelines.

The Government envisaged that the tariff levels for particular sizes and types of development would be set through supplementary planning guidance, action plans or topic plans. The Government considered that some locations would attract a higher tariff than others and that greenfield development would almost certainly have a higher tariff than brownfield developments, which might be exempted altogether. A number of options were put forward by the Government as to how a tariff might be set, for example on a cost per gross floor space basis for both commercial and residential development; on a cost per dwelling basis for residential development and gross floor space for commercial development; or as a proportion of development value or some combination of these. It sought views on the best approach.

The Government also sought views about where the size threshold should be set and whether it should be determined nationally, regionally or locally. It opened the 
debate by putting forward an option which would exempt developments below 200 square metres of gross commercial floor space or 150 square metres of residential floor space from any requirement to pay a tariff. These were very low thresholds.

In the consultation paper the Government acknowledged that tariffs alone would not provide the flexibility to deal with all development circumstances. The consultation paper stated that in some cases there would be specific constraints that needed to be addressed where a planning obligation could remove an impediment to development, for example the need to deal with site conditions or access. The tariff might therefore need to be supplemented or amended by a negotiated agreement. The Government suggested that in those circumstances it should result in a single planning obligation being negotiated around the tariff.

\section{HOUSE OF COMMONS SELECT COMMITTEE ON TRANSPORT, LOCAL GOVERNMENT AND THE REGIONS - THIRTEENTH REPORT: PLANNING GREEN PAPER (JULY 2002)}

Following the publication of the Planning Green Paper and the companion consultation paper on Planning Obligations, the House of Commons Select Committee on Transport, Local Government and the Regions decided to hold an Inquiry and sessions were held in April and May 2002. Their Report was published on 1 July 2002.

The Select Committee, criticised the sketchiness of the proposals on how the tariff system would work in detail and came to a number of conclusions and recommendations:

- "The Government's proposals for tariffs would replace one form of complexity with another. Instead of site by site negotiated solutions after the submission of planning applications, enormous effort would be required to establish the basis for tariffs around the country, authority by authority, at the forward planning stage."

- "There is a danger that the change to the tariff system will affect the Government's grant to local authorities."

- "The Government needs to undertake substantially more work to demonstrate that funding affordable housing by tariff rather than by the current system of negotiation will clearly produce significantly more affordable housing."

- "We feel that the proposal to introduce a tariff requires considerable further development before the Committee can take a view on whether it is workable."

It is perhaps a pity that this influential and often controversial Select Committee did not seek to put forward their own views on planning obligations and how the system might be reformed.
The proposed tariff system also caused widespread concern amongst the development industry. The main concern was that the proposed tariff system was seen as a proposed new tax on development values and that there was a lack of detail as to how it would work.

The House Builders Federation raised fundamental objections to the proposed tariff. They commented:

"The current package would negate much of what

Government seeks to achieve and compromise its core policy

objectives on economic growth and prosperity, urban

regeneration and access to decent housing”.

The CBI opposed the Government's proposed tariff. Digby Jones, the Director General of the CBI, said the proposals were "nothing less than a stealth tax on regeneration and a major obstacle to companies that want to help councils create wealth and jobs". According to CBI estimates the change would cost business an extra £2 billion per annum.

The British Property Federation attacked the proposals as "yet another stealth tax", and said:

"The Government has it wrong. The Paper proposes all the things that we didn't want planning gain to become. It is shifting the tax burden for social improvements on to the property industry. The Government is in danger of killing the goose that lays the golden egg. It seems to have forgotten that property is a global enterprise. Companies don't have to take this - they can go elsewhere".

\section{THE GOVERNMENT'S RESPONSE TO THE GREEN PAPER CONSULTATION EXERCISE (JULY 2002) AND TO THE SELECT COMMITTEE REPORT (NOVEMBER 2002)}

On 18 July 2002 John Prescott, the Deputy Prime Minister, who had taken over the planning brief in May 2002, made a statement to the House of Commons on the Government's plans for what he called a step change in the Government's policies for housing and planning. In relation to planning the Deputy Prime Minister referred to the provision of extra resources for the planning system and proposals for reform. In his statement he made reference to the publication on that date of three documents: the Government's response to the Planning Green Paper consultation exercise and supporting papers on compulsory purchase and on regional and local plans. Did he mention tariffs and reform of the system of planning obligations in his statement? No, there was no mention of this. That seemed very surprising as the proposals for a tariff system had been central to the Government's proposed reforms.

The Government's response to the Green Paper Consultation exercise, one of the three documents referred to by the Deputy Prime Minister in the House of Commons on 18 July 2002, was a paper entitled Sustainable Communities - Delivering through Planning. This set out the 
Government's plans for transforming the planning system to make it faster, fairer and more predictable. What was said about reform of planning obligations?

Paragraph 52 of the paper stated as follows:

"Our consultation document proposed several options for reforming the system of negotiated planning obligations (also known as s 106 agreements). The lead option was to replace the negotiated agreements as far as possible, by a locally set tariff. The aim was to address concerns about the lack of openness of negotiated agreements, about the delays that they can cause to the planning process and about the lack of certainty for developers."

Paragraph 53 stated:

"The objectives of our tariff proposal were widely welcomed by a majority of respondents to consultation, subject to seeing the details. We have decided that many of our objectives can be delivered without legislative change. We will revise our policy guidance and work with all the relevant stakeholders to create a more streamlined system that will enable the community to share in the benefits arising from development [underlining added]. We will also carry forward the measures in the consultation paper for making the present system more transparent and predictable. For example, we have already required planning obligations to be entered on the planning register to ensure that they are open to public inspection."

With no acknowledgement whatsoever to its having performed a volte-face, the Government had scrapped its tariff proposals at a stroke.

What had happened to tariffs? A press release issued by the Office of the Deputy Prime Minister on 18 July 2002 was hardly any more illuminating than the response document. That stated that there would be changes to the section 106 planning obligations system, to make it more transparent and simple. It was also stated that there would be no new legislation to introduce a tariff, but new guidance would be issued on how planning obligations would work.

It would appear then that the Government had caved in to industry pressure from bodies such as the CBI and the British Property Federation who had condemned the tariff proposals as a stealth tax, and to the criticisms of tariffs made by the Select Committee in its Report on the Planning Green Paper. The Government seemed to have accepted that the question of tariffs and establishing a tariff system was a hugely complex subject and that they had underestimated how difficult it would be to introduce a tariff system. They had therefore decided to scrap the proposals.

On 6 November 2002 the Government published a response to the House of Commons Transport, Local Government and the Regions Select Committee Report on the Planning Green Paper. Their response was essentially a repeat of what had been set out in the Sustainable
Communities - Delivering through Planning paper of 18 July 2002.

\section{CARRY OVER OF THE PLANNING AND COMPULSORY PURCHASE BILL - JUNE 2003}

The Planning and Compulsory Purchase Bill was deposited in Parliament in December 2002 and received its Second Reading in the House of Commons on 17 December 2002. As anticipated there was nothing in the Bill about tariffs or indeed any proposals for legislation in relation to planning obligations.

On 10 June 2003 the House of Commons voted to carry over the Planning and Compulsory Purchase Bill into the next session of Parliament. During the debate on the carryover motion Tony McNulty, the then Parliamentary Under Secretary of State commented, in response to questions raised by MPs about what was happening regarding planning obligations reform and points made by MPs that there should perhaps be legislation, that it was never intended that planning obligations reform should be part of the Bill. He said that bemoaning their absence seemed rather strange.

On 12 June 2003, a few days after the decision to delay the Bill, the Government announced a ministerial reshuffle. Lord Rooker, the Planning Minister, became Minister for Regeneration and the Regions. He was replaced as Planning Minister by Keith Hill, formerly Deputy Chief Whip in the House of Commons.

\section{CONSULTATION PAPER CONTRIBUTING TO SUSTAINABLE COMMUNITIES - A NEW APPROACH TO PLANNING OBLIGATIONS (NOVEMBER 2003)}

On 6 November 2003, the Government, after considerable delay, issued a consultation paper entitled "Contributing to Sustainable Communities - A New Approach to Planning Obligations". The consultation document set out the Government's proposals for reforming and improving planning obligations. The objective was stated to be to provide greater transparency and certainty for all stakeholders and help enable developers and local planning authorities to avoid the delays that sometimes occur under the current system. The Government stated that they proposed to reform planning obligations policy to improve negotiated planning obligations and to legislate to enable the Government to establish a new optional planning charge as an alternative to negotiated planning obligations to be set within Local Development Frameworks. The period of public consultation was to last for 9 weeks rather than the usual 12 weeks and responses were to be submitted to arrive at the ODPM by 8 January 2004. The proposal for an optional charge came as a major surprise so soon after the 
Government's decision in July 2002 to abandon its original proposal for a planning tariff.

In announcing the proposal, the Planning Minister, Keith Hill, commented:

"The planning system has the potential to deliver so much for the community, from affordable homes to health centres to parks and open spaces. The problem is the system is simply too slow and fails to deliver what is needed when it is needed. We need a radical solution to simplify and speed up the process.

This new optional charge is the solution. It will give developers a choice. If they wish to negotiate a traditional section 106 agreement, then they can, but if they want greater speed and certainty, they can pay the charge, leaving them free to get on with things and the local authority with the resources to spend on community projects - green travel plans, education facilities or road improvements. That is good news all round".

\section{PLANNING AND COMPULSORY PURCHASE BILL - PLANNING CONTRIBUTIONS}

In early December 2003, the Government introduced into the House of Commons, midway through the consultation period, amendments to the Planning and Compulsory Purchase Bill to give effect to the proposed optional planning charge which were adopted. Three clauses were promoted under the heading "Planning Contribution". These new clauses were a replacement for sections 106, 106A and 106B of the 1990 Act as substituted by the Planning and Compensation Act 1991. The Government issued an explanatory note on the new clauses explaining how the proposed system would operate which stated that:

"The purpose of the new clauses is to introduce an alternative means for developers to make contributions towards services and facilities related to the development they wish to promote without the need to negotiate with the local planning authority. Those undertaking development may agree to pay to a local planning authorities an amount set out in a document, drawn up by the local planning authority, as an alternative to most or all of the negotiated agreements which are currently made. In order to secure this, the clauses seek to repeal section 106 and replace it with two mechanisms, which together are designed to have the same effect as section 106 does now. The provisions retain the existing negotiated route while also providing for a set contribution payable by developers.

The clauses rename 'planning obligations' as 'planning contributions'.

The powers proposed enable the Secretary of State to introduce planning contributions and to provide for how planning contributions will operate in regulations. This approach has been taken because the Government is currently consulting on the way in which the new planning contribution will operate, and therefore seeks some flexibility as to the final details of the proposals. However, the regulations will be subject to affirmative resolution of each House of Parliament and therefore there will be opportunity for scrutiny of the regulations before they are made".

\section{"Planning contributions clause}

1. empowers the Secretary of State to make provision, by regulation, for local planning authorities to accept a planning contribution in relation to the development or use of land in its area.

2. permits that the planning contribution may occur in two forms. Firstly, 'the prescribed means', which are defined at (5) and which provides for the payment of a contribution calculated in accordance with the criteria set out by the local planning authority. In the Government's consultation document the prescribed means are referred to as an optional planning charge. Secondly, 'the relevant requirements', which are defined at (6) and which provides for negotiated planning contributions, equivalent to the existing planning obligations system. Thirdly, the subsection also provides that it will be possible to offer a planning contribution by both routes (but see also comments on subsection (4)).

3. enables the Secretary of State to require local planning authorities to include in a development plan document, or other prescribed document, the matters set out in (a) to (d), namely: (a) the types of developments for which it is likely to seek a contribution (whether by the optional charge or negotiated route); (b) developments where a contribution via the charge will not be sought; (c) how funds obtained through planning contributions will be used by the LPA and (d) how any contribution will be calculated. Collectively these are referred to in this note as the local planning authority's planning contributions policy.

4. provides for the Secretary of State to make regulations relating to the means by which a planning contribution may be made. (a) enables regulations to provide that the person making the planning contribution must indicate that he wishes to make the contribution by paying the optional planning charge (the prescribed means) set by the LPA, rather than negotiate the terms of his contribution (by way of relevant requirements). (b) enables regulations to provide that where a contributor makes a contribution through the charge (prescribed means), he is not also required to make the same contribution through a negotiated agreement (the relevant requirements), and vice versa. This provision is designed to ensure that developers are not asked to contribute twice in relation to the same matters. (c) enables regulations to provide that where a contribution has been made by compliance with the relevant requirements it may not be made by the prescribed means. Again, this provision is designed to ensure that developers are not asked to 
contribute twice in relation to the same matters. (d) enables regulations to provide for circumstances when no contribution must be required by the LPA.

5. defines the prescribed means. The prescribed means may be: the payment of a sum calculated in accordance with the criteria set by the LPA in the development plan document or other prescribed document under subsection (3) (see above); or the provision of a benefit in kind, the value of which is calculated in accordance with the criteria in the development plan document or other prescribed document under subsection (3); or a combination of both.

6. defines what is meant by the relevant requirements. These will be such requirements prescribed and set out in the terms of the contribution.

The Government intends that where the contributor does not wish to make a contribution through the prescribed means, he may negotiate to provide that contribution. Furthermore, there will be circumstances (even where a planning contribution is made by prescribed means) where a negotiation may still be required. These matters will usually be specific to the development site itself, such as provision of adequate access. The relevant requirements will enable both types of negotiated agreements to proceed".

\section{"Regulations clause}

The proposed Regulations clause provides further detail of the Regulations that the planning contributions clause empowers the Secretary of State to make. It is proposed that all regulations made in relation to planning contributions should be subject to the affirmative resolution procedure.

1. confirms that the provisions relating to regulations set in this section apply to the planning contributions section only.

2. provides that the Secretary of State may specify maximum and minimum amounts that may be prescribed by an $L P A$, where a planning contribution is offered by the prescribed means.

3. provides that the Secretary of State may make regulations allowing periodic adjustment of the criteria by which the LPA will determine the value of a contribution by the prescribed means. This is intended to allow amounts set by the prescribed means to be automatically uprated according to an index such as the RPI or a construction prices index without having to review the document in which the planning contributions policy (and therefore the amounts prescribed) are published.

4. provides that the Secretary of State may require LPAs to publish an annual report on planning contributions. Regulations would set out the matters on which local planning authorities should report - these might include the matters in relation to which a planning contribution has been sought, and how receipts from the prescribed means have been spent.
5. enables the Secretary of State, where a document other than a development plan document will contain the matters where a planning contribution will be sought, to set out the procedure for the preparation and publication of the LPA's policy on planning contributions. It also provides, at (b), that the Secretary of State may himself take steps in relation to the preparation of such a document - for example, where the local planning authority fails to prepare one.

6. empowers the Secretary of State to make regulations concerning the enforcement of planning contributions. These may include three specific matters - (a) binding persons deriving title in the land, to which the planning contribution applies, to the terms of the planning contribution; (b) enabling the Secretary of State to attach a condition to a planning permission requiring the payment of the planning contribution prior to the commencement of development and (c) to include the enforcement of planning contributions made in relation to Crown Land.

7. (a) enables regulation to provide that the LPA may only apply receipts of contributions obtained by prescribed means to the matters described by the local planning authority in its planning contributions policy set out in a development plan document or such other document prescribed.

(b) enables the Secretary of State to make provisions as to how the terms of the planning contribution will be set out. In the case of a negotiated agreement as to relevant requirements, it is envisaged that the terms of the contribution will be through a legal document similar to the current system contemplated by section 106 of the Town and Country Planning Act 1990. In the case of contributions made by the prescribed means, it is envisaged that regulations will set out a standard form of agreement.

(c) enables the Secretary of State to make provisions in relation to the modification and discharge of a planning contribution. These matters are currently covered by section $106 \mathrm{~A}$ and $106 \mathrm{~B}$ in the Town and Country Planning Act 1990, which we propose to repeal and to replace with similar provisions in Regulations.

8. enables the Secretary of State to provide different provisions for different areas or descriptions of local authorities and exclude the application of the regulations to particular areas or descriptions of local authorities".

\section{"Planning Contributions: Wales clause}

This clause confers upon the National Assembly for Wales the same powers in relation to the planning contribution as the Secretary of State has for England; and the local development plan is substituted for the development plan document as the document in which (unless another document is prescribed) planning contributions should appear". 


\section{"Other clauses}

Other proposed clauses:

- Addition of the regulation-making powers proposed above with the general regulation-making power sought at clause 114 of the Bill;

- Provision that in the case of the planning contribution, regulations should be subject to the affirmative resolution procedure.

- Provision that sections 106, $106 \mathrm{~A}$ and 106B of TCPA 1990 are to be repealed".

\section{CONSIDERATION OF THE BILL BY THE HOUSE OF COMMONS AND THE HOUSE OF LORDS}

On the first day of the Report Stage in the House of Commons on 8 December 2003, Keith Hill, the Planning Minister, explained that the Government had shortened the consultation period for the consultation period issued on 6 November 2003 from 12 weeks to nine weeks on the basis that the Government were looking for broad views on the general principles. He explained that a further more detailed consultation document would be issued in the Spring of 2004 in the form of a draft circular setting out firmer and more detailed proposals. After that second consultation period, the Government would then publish a new revised circular to replace circular 1/97. Mr Hill said that, in a nutshell, the Government had decided that they wanted to take advantage of this rare legislative opportunity to introduce the optional planning charge. He said that planning Bills were not introduced frequently and the opportunity might not arise again for years. There was considerable disquiet on the part of Opposition MPs that the amendments were being promoted before the consultation process had been completed that they threatened a judicial review of the Government's decision to introduce them. There was opposition to the proposed clauses in the House of Commons but the Bill was given a Third Reading and was referred to the House of Lords.

The Bill received its first reading in the House of Lords on 10 December 2003. In the Second Reading debate on 6 January 2004, there was considerable opposition to the proposals for the optional charge from Lord Best, Baroness Hanham and Baroness Maddock. There was major concern as to the impact of the proposed optional charge on the provision of affordable housing compared with the present Section 106 system.

The House of Lords considered the planning contribution clauses in Committee on 2 and 5 February 2004. There was concern that the Government was seeking to rush through these clauses without heed to the opposition being expressed to the proposals. At the House of Lords Report Stage on 16 March 2004, there were calls for the clauses dealing with planning contributions to be deleted because of the incoherence of the Government's proposals.

At the House of Lords Third Reading debate on 25 March 2004, Baroness Hanham said that she still had no idea what the tariff would involve. She said that the only saving grace was that the Government had made no case for hanging a sword over section 106 which appeared to be widely accepted by developers, and that section will be maintained. Baroness Maddock stated that she would have preferred to have seen an improved section 106 system, not another new tariff system. She said that there was still concern in relation to affordable housing. She also repeated that she wanted to keep a reformed version of section 106. She pointed to the lack of clarification on the provisions and the fact that all the detail will be in secondary legislation. She said it will be extremely difficult for the House to scrutinise the legislation properly and to have a proper input.

\section{STATEMENT BY THE ODPM - 30 JANUARY 2004}

An ODPM Parliamentary Statement under the heading "Contributing to Sustainable Communities - A New Approach to Planning Obligations" was issued on 30 January 2004. It referred to the Government's consultation exercise and stated that a summary of the consultation responses was to be published on 2 February 2004. The Government observed that in general the response to the consultation paper had been more mixed and moderate than the response to the Planning Green Paper consultation exercise. The Government acknowledged that the consultation responses expressed concern about the detail and practicalities of the optional planning charge. The statement then went on to address some of the concerns raised. One of the main concerns raised in the consultation exercise had been whether the new system would represent a development tax.

The statement made it clear that planning obligations would not become a development tax. It stated that: "the planning contribution offered by whichever route should be related to the impact of development and be relevant, proportionate and reasonable".

\section{RESPONSES TO THE CONSULTATION PAPER - 2 FEBRUARY 2004}

The Government issued a document on 2 February 2004 entitled "A New Approach to Planning Obligations Summary of Consultation Responses". This summarised the responses to the consultation paper launched on 6 November 2003. The Government had received over 340 responses.

The summary document made it clear that whilst many of the responses had been broadly supportive of the proposed optional charge, others had been concerned 
about the lack of information and firm policy guidance in the proposals.

\section{TASK FORCE}

At the Report stage of the Bill in the House of Lords on 16 March 2004, Baroness Hanham said that she understood that since the Committee Stage, the Government had set up a task force to consider the implications of making some changes to Section 106 provisions and to think through further the tariff systems and their implications. She thought that that was a strange situation. She said that the clauses were put into the Bill at a late stage in the Commons and it was clear that they had had no scrutiny there, at least no meaningful scrutiny, and they arrived in the House of Lords virtually untouched.

Baroness Hanham said that the tariff had been opposed all the way along the line. She said that if the taskforce were to be set up, its discussions would take place outside the terms of the Bill, and the House would not have an opportunity to discuss anything that was decided by it.

Lord Rooker announced that the Government was to set up a special advisory group of stakeholders to advise them on the reform of planning obligations. The decision to set up the special advisory group or task force was made following a meeting that Keith Hill had had with various lobbyists in the property world who were concerned that whilst there was a desire for reform of the planning obligations system there was an equally strong concern that the approach suggested by the Government might not work in practice. Lord Rooker said he was very grateful to the Royal Town Planning Institute and the other organisations that had expressed an interest in participating viz the British Property Federation, the Chartered Institute of Housing, the CBI, the Housebuilders Federation, the Local Government Association, the National Housing Federation, the Royal Institution of Chartered Surveyors and Shelter. He said that the group would meet regularly over the next few months to work through the details of the proposals. He said that Keith Hill would chair those meetings where possible. He said that the next months were critical in developing the detail of the new system so that the Government could look forward to the valuable input of the special advisory group on the shape of the reforms. He said that they would also seek its views on the draft Regulations, the Circular and the proposed Good Practice Guide.

Lord Rooker made it clear that he would ensure that before the House was presented with a final decision, it would at least get a report from the special advisory group so that the House would know in advance what was happening.

Baroness Maddock said that the Government had got this all the wrong way around. She said that we have had the Bill and we have had consultation and now we are having a task force. She said it should have been the other way round.

In the Third Reading debate in the House of Lords on 25 March 2004, Baroness Hanham said that she understood that the task force had been set up and that it was due to report by September 2004. She said she understood that they had not had an auspicious start. She said that an initial scoping meeting was held and a provisional date of 23 March was agreed for its first meeting. That did not take place, and no subsequent date has been set. She said that that does not set a good precedent for the importance that the Government attached to the taskforce. She asked whether the Minister could explain why the meeting did not take place and whether it was envisaged that the six month programme, which will not be completed until September, is still on target.

Lord Rooker said that the advisory group had been due to have had its first meeting that week, but that it had been postponed until April to give time to reflect on the implications of the Barker proposals. He said that the stakeholders were quite content with the arrangements for taking on what Barker had said and having the first meeting in April.

\section{PILOT SCHEMES}

In the House of Lords debate on 2 February 2004, Baroness Maddock expressed concern as to how local authority planning departments would deal with the new system. She pointed to the fact that there had been no pilot schemes to the best of her knowledge and concern was echoed by Lord Lucas.

Lord Rooker was taken with the idea of pilot schemes and agreed to take back the suggestion of having such a scheme. Keith Hill has now pledged to launch pilot schemes for the tariff before it is rolled out across the country to prevent it from becoming the administrative nightmare for planners that lobbyists believe.

\section{BARKER REPORT}

In December 2003, Kate Barker issued her interim report entitled Review of Housing Supply - Securing our Future Housing Needs which contained an analysis of planning obligations.

In the overview of her interim report Kate Barker considered the influence of planning and in relation to planning obligations stated the following:

"A19 The development control process also usually includes the negotiation of planning obligations, which are designed to enhance the quality of development and to enable development to proceed where it might otherwise be prevented by specific on site factors or its impact on the community. The current legislation relating to planning obligations is set out in section 106 of the Town and Country Planning Act 1990. 
The Government recently issued a consultation on proposals to reform planning obligations by introducing an optional charge, which developers could choose in place of negotiating a S106 agreement.

A20 Section 106 is not designed to capture planning gain. Rather, it should be used to compensate for the impacts of development and provide necessary infrastructure and services to make the development viable. These obligations are imposed at the point that planning permission is granted because it is at this point that developers and land owners gain from the increase in land values associated with the granting of a permission. Planning obligations seek to extract some of this gain for the benefit of the local community in order to compensate them for the loss of amenity and pressure on infrastructure brought about by development."

There were clear indications from this that Kate Barker had it in mind to suggest in her final report changes to seek to capture planning gain.

Kate Barker's final report entitled Review of Housing Supply - Delivering Stability: Securing Our Future Housing Needs was published on 17 March 2004. It called for between 70,000 and 120,000 extra homes to be provided every year and an overhaul of planning law to speed up development. The report acknowledged that section 106 needs reform to provide more certainty and simplicity and noted that the Government was consulting on one way to achieve this. However the report stated that if her recommendation to introduce a planning gain supplement, which would be a tax on the uplift in land value created by planning permissions, were to be accepted this would offer the opportunity to achieve this objective by scaling back section 106 to cover the direct impact of development and contributions to social housing only.

Kate Barker thought that the Government's tariff proposals would be second best and recommended that section 106 agreements should be "reined back" to cover the impact of schemes alone. A windfall tax or planning gain supplement could cover the losses. The supplement, based on the value of the land, would not be less than the money lost by restricting section 106, she explained. The relevant recommendations were recommendations 24 and 26, the full text of which reads as follows:

\section{"Recommendation 24}

Section 106 should be reformed to increase the certainty surrounding the process and to reduce negotiation costs for both local authorities and developers.

If the Government accepts the recommendations outlined in Chapter 4 concerning the capture of development gains:

- Section 106 should be 'scaled back' to the aim of direct impact mitigation and should not allow local authorities to extract development gain over and above this, except as indicated below. ODPM should issue guidance, or new legislation, to this end.
- Section 106 should retain its current affordable and/or social housing requirements as set out in circular 6/98, and other specific regional guidance.

- Local authorities should receive a direct share of the development gain generated by the planning-gain supplement in their area, to compensate for a reduced Section 106. Local authorities should be free to spend this money as they see fit. This share should at least broadly equal estimates of the amount local authorities are currently able to extract from section 106 agreements.

"If the Government decides to maintain the current fiscal framework as it is, then it should press ahead with the section 106 reforms, on which it has recently consulted, that aim to introduce an optional planning charge in place of a negotiated agreement. However, this would be second best and leaves open the possibility of prolonged and costly section 106 negotiations for large developments".

\section{“Recommendation 26}

Government should use tax measures to extract some of the windfall gain that accrues to landowners from the sale of their land for residential development.

Government should impose a planning-gain supplement on the granting of planning permission so that landowner development gains form a larger part of the benefits of development.

The following principles might be considered:

- Information would need to be gathered as to the value of land proposed for development in each local authority. Sources of data could include actual transactions and/or Valuation Office Agency estimates as to the land prices in various local authority areas.

- Government would then set a tax rate on these values. This tax rate should not be set so high as to discourage development, but at a rate that at least covers the estimated local authority gain from section 106 developer contributions and provides additional resources to boost housing supply.

- The granting of residential planning permission would be contingent on the payment of the supplementary planning contribution of the proposed development.

- Government may want to consider the operation of a (substantially) lower rate for housing development on brownfield land, and the possibility of varying rates in other circumstances, e.g. for areas where there are particular housing growth strategies, or where other social or environmental costs may arise.

- A proportion of the revenue generated from the granting of planning permissions in local authorities should be given directly to local authorities. Government should also amend the operation of section 106 planning obligations, as set out in Chapter 3, to take account of this new charge. 
- The Government may want to consider allowing developers to pay their contributions in instalments over reasonable time periods so as to ensure that housebuilder cash flow pressures are sufficiently accounted for.

The introduction of a tax would need to be accompanied by transitional measures to ameliorate the impact on developers already engaged in land sales contracts that were drawn up before this charge was introduced, or for those who hold large amounts of land already purchased, but where planning permission has yet to be secured".

In his Budget statement on 17 March 2004, the Chancellor of the Exchequer stated, in relation to the Barker Report, that while the business rate sets a tax on developed properties, there is none on the unearned increment in land values when undeveloped land is granted planning permission. Because this is a long-term issue important for both housing and stability, the Chancellor said that the way forward was not only to consult widely but to see whether a long-term consensus could be agreed. He hoped that over the next year, all parties would study the Barker proposal and stated that it must be in the interests of the whole country to see whether we can forge a shared approach that would safeguard our environment, lead to more affordable housing, and at the same time keep interest rates as low as possible and contribute to the greater economic stability of Britain.

In a press notice the Government accepted that it is, in principle, fair to fund measures to help in the expansion of housing supply out of the uplift in land values experienced during the development process. This could also alter the balance of incentives between greenfield and brownfield development, helping to encourage a more efficient use of land.

The publication of the final Barker Report was referred to in the Third Reading of the Bill in the House of Lords on 25 March 2004, Baroness Hanham referred to Kate Barker's findings that tariffs were second best and that what Kate Barker wanted was a proper planning development tax which was not provided for in the Bill.

Lord Rooker gave an initial response to the Barker recommendations, saying that the Chancellor of the Exchequer was not going to rush to judgment on this substantial issue. He said he did not think that the Barker conclusions or the Chancellor's proposal caused any change to the Government's policy approach and that he regarded the reform of planning obligations as urgent in view of the widespread criticism that there had been of the present arrangements.

Lord Rooker also said that it should be noted that Kate Barker had said that if the Government decided not to proceed with their suggestion of a planning gain supplement, it should proceed with its present package of reforms offering the choice of a charge or negotiation. Were the Chancellor to decide in due course to

proceed with a planning gain supplement, he said that the provisions in the Bill would allow the Government to adjust their proposals to make them, if need be, complementary to the planning gain supplement.

Lord Rooker added some might suggest that, in the event of the Government accepting Barker's recommendations, they might move to a framework for planning obligations using only the negotiated route. That would present a reason for deleting the clauses and the provision for an optional charge. He said, however, that that overlooked a significant point. He said that an important advantage of reconstituting section 106 in regulations is that it would allow the Government to ensure that planning contributions that are negotiated or contained in unilateral undertakings could be limited in future to direct impacts and affordable housing - that is, the Barker approach - if that is the route we decide to follow in due course. He said that under the present law we do not have that flexibility. Therefore, maintaining this approach and proceeding with the Bill as it is gives us the flexibility for converting section 106 into the regulations.

In reply, Baroness Hanham said that she was shocked and almost speechless. She said that the Government should withdraw all these clauses and put them into different legislation that everyone can examine. She said it was outrageous that legislation should go through in this hibbledy-hobbledy way, one minute to be told that the clauses were included and the next to be told that the whole thing is effectively going to be reviewed on the back of Kate Barker. She said that she was very tempted to test the opinion of the House. She did not do that, but thought that there was a big mess here. She said it was very serious that this should arise at this late stage of the Bill.

Given the potential conflict between the Government's proposals for introducing planning contributions and the land tax proposals in the Barker Report, it might have been thought sensible for the Government to have delayed their proposals on planning contributions until the proposed consultation exercise on the Barker recommendations had been carried out. That is not to be and it is understood that the Government are intent on proceeding with their planning contribution proposals notwithstanding this conflict.

Michael Cunliffe
Partner, Forsters Solicitors
Michael specialises in planning law. He is a Legal Associate of the
Royal Town Planning Institute and member of the Law Society's
Specialist Planning Panel. He is a member of the Planning and
Environmental Law Reform Working Group of the Society for
Advanced Legal Studies and a member of the City of London Law
Society's Planning and Environmental Law Sub-Committee.
Michael has developed a particular expertise in the field of
planning obligations/planning gain and he has negotiated
numerous complex agreements both on behalf of developers and
local planning authorities. Michael has lectured on planning law
and written articles for planning journals. He gave a paper at the
Oxford Joint Planning Law Conference in September 2001
entitled "Planning obligations - where are we now?"

